\title{
Temporal changes in milk fatty acid composition during diet-induced milk fat depression in lactating cows
}

\author{
H. Leskinen, ${ }^{1 *}$ L. Ventto, ${ }^{1}$ P. Kairenius, ${ }^{1}$ K. J. Shingfield,${ }^{1} \dagger$ and J. Vilkki ${ }^{2}$ \\ ${ }^{1}$ Milk Production, Natural Resources Institute Finland (Luke), FI-31600 Jokioinen, Finland \\ ${ }^{2}$ Animal Genetics, Production Systems, Natural Resources Institute Finland (Luke), Fl-31600 Jokioinen, Finland
}

\section{ABSTRACT}

Diet-induced milk fat depression (MFD) in lactating cows has been attributed to alterations in ruminal lipid metabolism leading to the formation of specific fatty acid (FA) biohydrogenation intermediates that directly inhibit milk fat synthesis. However, the mechanisms responsible for decreased lipid synthesis in the mammary gland over time are not well defined. The aim of this study was to evaluate the effect of diet on milk FA composition and milk fat production over time, especially during MFD, and explore the associations between MFD and FA biohydrogenation intermediates in omasal digesta and milk. Four lactating Finnish Ayrshire cows used in a $4 \times 4$ Latin square with a $2 \times 2$ factorial arrangement of treatments and 35-d experimental periods were fed diets formulated to cause differences in ruminal and mammary lipid metabolism. Treatments consisted of an iso-nitrogenous total mixed ration based on grass silage with a forage to concentrate ratio of $65: 35$ or 35:65 without added oil, or with sunflower oil at $50 \mathrm{~g} /$ $\mathrm{kg}$ of diet dry matter. The high-concentrate diet with sunflower oil (HSO) induced a 2-stage drop in milk fat synthesis that was accompanied by specific temporal changes in the milk FA composition. The MFD on HSO was associated especially with trans-10 18:1 and also with trans-9,cis-11 conjugated linoleic acid (CLA) in milk and omasal digesta across all diets and was accompanied by the appearance of trans-10, cis-15 18:2. Trans-10,cis-12 CLA was increased in HSO, but milk fat secretion was not associated with omasal or milk trans-10,cis-12 CLA. The temporal changes in milk fat content and yield and milk FA composition reflect the shift from the predominant ruminal biohydrogenation

Received October 16, 2018.

Accepted January 29, 2019.

*Corresponding author: heidi.leskinen@luke.fi

$\dagger$ Deceased. pathway to an alternative pathway. The ambiguous role of trans-10,cis-12 CLA suggests that trans-10 18:1, trans-9,cis-11 CLA and trans-10,cis-15 18:2 or additional mechanisms contributed to the diet-induced MFD in lactating cows.

Key words: ruminant, dairy cow, plant oil, trans fatty acid

\section{INTRODUCTION}

Ruminant-derived foods are a significant source of saturated fat in the human diet (Kliem and Shingfield, 2016). Therefore there is considerable interest in altering the fatty acid (FA) composition of dairy products without losing the benefits of other nutrients present in milk. The diet of dairy cows is a central factor in regulating the concentration and composition of milk fat. Supplementation of dairy cow diets with oilseeds and plant oils lower the concentrations of nutritionally undesirable SFA such as 12:0, 14:0, and 16:0, and increase cis-9 18:1 and PUFA in milk (Kliem and Shingfield, 2016). However, diets supplemented with plant or marine oils, diets containing highly fermentable components, and low fiber-high concentrate diets are known to induce milk fat depression (MFD) in lactating cows (Bauman and Griinari, 2003). In MFD, milk fat yield is reduced without changes in milk yield or other milk components (Shingfield et al., 2010). Therefore, understanding the influence of nutrition on the regulation of milk fat synthesis is essential not only for enhancing the nutritional quality of milk fat for consumers but also for preventing MFD and using MFD in some cases to attenuate negative energy balance at early lactation as milk fat represents an important energy loss for lactating cows (Bauman and Griinari, 2003; Shingfield et al., 2010).

Milk fat depression is a result of an interaction between dietary nutrients, rumen microbiota, and the mammary gland (Rico and Harvatine, 2013). Nutritional studies over the past decades have made considerable progress in understanding the effects of rumen lipid metabolism and milk fat synthesis, but studies 
investigating the temporal changes in MFD are scarce. The time-dependent effects of a mixture of fish oil (FO) and sunflower oil (SO; Shingfield et al., 2006), SO (Roy et al., 2006), FO (Gama et al., 2008), and soy oil (Rico and Harvatine, 2013) incorporated in different basal diets on milk fat secretion and milk FA composition and the effects of SO and starch level on FA composition in the rumen digesta of dry cows over time (Zened et al., 2013) have been outlined in previous experiments. Several hypotheses have been proposed to explain dietinduced MFD in dairy cows. The most recent and most widely accepted is the biohydrogenation (BH) theory of diet-induced MFD (Bauman and Griinari, 2001), which suggests that the changes in ruminal lipid metabolism, mainly a shift from the trans-11 to trans-10 pathway, increase the formation of specific $\mathrm{BH}$ intermediates from dietary PUFA that inhibit milk fat synthesis (Bauman and Griinari, 2001, 2003). Trans-10,cis-12 CLA is the only intermediate that is known unequivocally to lower milk fat synthesis in lactating cows (Baumgard et al., 2000; Glasser et al., 2010; Harvatine and Bauman, 2011). However, the earlier findings suggest that other intermediates, such as cis-10,trans-12 CLA (Saebø et al., 2005) and trans-9,cis-11 CLA (Perfield et al., 2007) may exert a potential antilipogenic effect. In addition, other unidentified $\mathrm{BH}$ intermediates or mechanisms may also contribute to the regulation of fat synthesis in the bovine mammary gland during MFD.

In a companion paper (Ventto et al., 2017), the ruminal $\mathrm{BH}$ intermediates were characterized in cows fed a high or low concentrate diet containing no additional lipid or SO. The treatments were formulated to cause varying effects on ruminal lipid metabolism and milk fat synthesis. High-concentrate diet supplemented with SO decreased milk fat synthesis up to $-31.9 \%$, but ruminal trans-10,cis-12 CLA outflow did not explain the lowered milk fat synthesis. The present paper from the same experimental setup provides more information about the responses in the mammary gland. Data related to animal performance, ruminal methane emissions, omasal flow of FA (Bayat et al., 2017; Ventto et al., 2017), and ruminal microbial ecology (Tapio et al., 2017) were published earlier. The aim of this study was to test the hypothesis that ruminal synthesis of specific $\mathrm{BH}$ intermediates and end products with known or putative anti-lipolytic activity appear in milk fat and explain the decrease in milk fat synthesis on a diet causing MFD. The study describes the time-dependent changes in milk fat and FA composition in cows fed diets formulated to induce variable effects on FA metabolism and milk fat synthesis to understand the role of ruminal FA BH intermediates in MFD in lactating cows.

\section{MATERIALS AND METHODS}

\section{Animals, Experimental Design, and Diets}

All experimental procedures were approved by the National Ethics Committee (ESAVI/794/04.10.03/2011, Kuopio, Finland) in accordance with the guidelines established by the European Community Council Directive 86/609/EEC (European Council, 1986). Details on experimental animals, treatments, experimental design, sampling, and chemical analysis have been reported in a companion paper (Ventto et al., 2017). In brief, 4 multiparous Finnish Ayrshire cows $(89 \pm 11.8$ d postpartum) fitted with rumen cannulas (i.d. $100 \mathrm{~mm}$, Bar Diamond Inc., Parma, ID) were used in a $4 \times 4$ Latin square design with a $2 \times 2$ factorial arrangement of treatments. Each experimental period consisted 14-d diet adaptation, 12-d sample collection interval, and 9-d washout. Treatments consisted of iso-nitrogenous diets based on grass silage [forage to concentrate (FC) ratio 65:35 and 35:65 on a DM basis, respectively] containing either 0 (treatments $\mathbf{L}$ and $\mathbf{H}$, respectively) or $50 \mathrm{~g} / \mathrm{kg}$ of diet DM of SO (treatments LSO and HSO, respectively). Diets were formulated based on Finnish Feed Tables (Luke, 2018); offered ad libitum at 0600, 0900, 1630, and $1930 \mathrm{~h}$; and fed as a TMR to avoid selection of dietary components and maintain the desired FC ratio. Cows were housed in individual tiestalls in a dedicated metabolism unit with free access to water and salt block, and milked at 0700 and $1645 \mathrm{~h}$.

\section{Sampling and Chemical Analysis}

Intake of all cows was measured daily, and representative feed samples were collected daily from d 21 to 25 of each period, and analyzed for chemical composition (Shingfield et al., 2001, 2002; Ventto et al., 2017). Daily milk yields and milk composition of all cows were recorded throughout the experiment (Ventto et al., 2017). Unpreserved samples of milk at each milking were collected, composited according to yield, and stored at $-20^{\circ} \mathrm{C}$ before submitting to $\mathrm{FA}$ analysis. The flow of digesta at the omasal canal was sampled and measured using the omasal sampling technique and $\mathrm{Cr}$, $\mathrm{Yb}$, and indigestible neutral detergent fiber as indigestible markers from d 22 to 24 as described by Ventto et al. (2017).

\section{Lipid Analysis}

The FAME of lipid in feed, omasal digesta, and milk samples were prepared as described earlier (Shingfield et al., 2003; Ventto et al., 2017). The FAME were ana- 
lyzed using a gas chromatograph (model 6890N, Agilent Technologies, Santa Clara, CA) fitted with a CP-Sil 88 column $(100 \mathrm{~m} \times 0.25 \mathrm{~mm}$ i.d., $0.2 \mu \mathrm{m}$ film thickness, Agilent Technologies) and flame ionization detector by using a temperature gradient program (Shingfield et al., 2003) and hydrogen as the carrier gas operated at constant pressure $(206.8 \mathrm{kPa})$ and nominal initial flow rate of $2.1 \mathrm{~mL} / \mathrm{min}$. Individual isomers of $18: 1$ were further resolved in a separate analysis under isothermal conditions at $170^{\circ} \mathrm{C}$ (Shingfield et al., 2003) at a constant pressure $(158.6 \mathrm{kPa})$ and a nominal initial flow rate of $0.9 \mathrm{~mL} / \mathrm{min}$. Under these conditions trans-10, cis- 15 18:2 and trans-11,cis-15 18:2 eluted as a single peak. To resolve these isomers, GC analysis was repeated using a SLB-IL111 column $(100 \mathrm{~m} \times 0.25 \mathrm{~mm}$ i.d., $0.2 \mu \mathrm{m}$ film thickness, Sigma-Aldrich, St. Louis, MO; Ventto et al., 2017). The FAME not available as authentic standards were identified by GC-MS (6890 and 5973; Agilent Technologies) analysis of FAME and 4,4-dimethyloxazoline derivatives prepared from total FAME according to earlier reports (Halmemies-Beauchet-Filleau et al., 2011). Distribution of CLA isomers was determined by $\mathrm{Ag}^{+}$-HPLC (Halmemies-Beauchet-Filleau et al., 2011). The CLA isomers and trans-10, cis-15 18:2 were determined in $\mathrm{d} 0,12,18,25$, and 35 samples.

\section{Statistical Analysis}

Milk FA data recorded during d 22 to 25 of each experimental period were averaged before statistical analysis and analyzed by ANOVA for a $4 \times 4$ Latin square design with a $2 \times 2$ factorial arrangement of treatments with a statistical model that included the fixed effects of period, concentrate level, SO supplementation, and their interaction, and the random effect of cow using the Mixed procedure of SAS (version 9.4, SAS Institute, Cary, NC). Milk composition and milk FA composition data over time were analyzed in 5 -d intervals (d 1-5, d 6-10, d 11-15, d 16-20, d 21-25, d 26-30, and d 31-35) by repeated measures ANOVA with a model that included the fixed effects of concentrate level, SO supplementation, their interaction (FC $\times \mathrm{SO})$, their interaction with time $(\mathrm{FC} \times$ time, $\mathrm{SO}$ $\times$ time, $\mathrm{FC} \times \mathrm{SO} \times$ time), time, and period, and the random effect of cow assuming an auto regressive order one covariance structure. Denominator degrees of freedom were calculated by the Kenward-Roger method. Relationship between flow of FA at the omasum, secretion of FA in milk and milk fat yield were evaluated by linear regression analysis using PROC REG procedure of SAS. Least squares means \pm standard error are reported, and treatment effects were considered significant at $P \leq 0.05$ and probabilities at $0.05<P \leq 0.10$ were considered as a trend.

\section{RESULTS}

Concentrate level by SO supplementation by time interaction over the 35-d experimental periods was significant $(P<0.01)$ for milk fat content and yield (Figure 1). The decrease in milk fat content of cows fed HSO occurred within $7 \mathrm{~d}$, decreased further until d 17, and recovered by d 34 (Figure 1A), whereas decline in milk fat yield was evident after d 17 (Figure 1B). Concentrate level by SO supplementation by time interaction over the 35-d experimental periods was not significant $(P>0.10)$ for milk yield and protein content (Supplemental Figure S1A and S1B; https://doi.org/ 10.3168/jds.2018-15860). Milk yield increased on HSO and $\mathrm{H}$ after start of the treatments and reached maximum concentration on d 6 to 8 .

Milk FA composition was affected by FC ratio and SO supplementation. In particular, high concentrate diets increased $(P<0.05)$ the proportions of 12:0, 14:0, 16:0, total cis $16: 1$, total $16: 1,20: 3 \mathrm{n}-6$, and $20: 4 \mathrm{n}-6$ in milk fat, and decreased $(P<0.05)$ 18:0, total cis 18:1, total 18:1, cis-9,trans-11,cis-15 18:3, 20:0, total cis 20:1, 20:4n-3, 20:5n-3, and 22:0 (Table 1). The SO supplementation lowered $(P<0.05)$ the proportion of 12:0, 14:0, 16:0, 18:3n-3, cis-9,trans-11,cis-15 18:3, 20:3n-6, 20:4n-3, 20:4n-6, 20:5n-3, 22:5n-3, 22:6n-3, and total SFA, but increased $(P<0.01)$ the proportion of total trans 16:1, 18:0, total cis 18:1, total trans 18:1, total 18:1, total MUFA, and total PUFA. Decreases in the proportions of 4:0, 6:0, 8:0, 10:0, cis-9 10:1, and $22: 5 n-6$ in milk fat were greater when SO was included in the $\mathrm{H}$ than $\mathrm{L}$ treatment $(P<0.05$ for $\mathrm{FC} \times \mathrm{SO}$ interaction). Increases in total CLA were greater when $\mathrm{SO}$ was included in the $\mathrm{L}$ than $\mathrm{H}$ treatment, whereas the reverse was true for nonconjugated 18:2 $(P<0.05$ for FC $\times$ SO interaction). The SO increased cis-9 14:1 when included in the $\mathrm{H}$ treatment, but decreased the proportions of this FA in milk on the $\mathrm{L}$ treatment $(P<$ 0.05 for $\mathrm{FC} \times \mathrm{SO}$ interaction; Table 1 ).

Irrespective of the $\mathrm{FC}$ ratio, $\mathrm{SO}$ supplementation increased $(P<0.05)$ the proportion of certain MUFA, such as cis-6 $16: 1+$ cis-7 $16: 1+$ trans- 11 16:1, cis-9 18:1 + trans-14 18:1, cis-13 18:1, cis-16 18:1 + cis8, cis-12 18:2, trans $(\Delta 4,9,12,13,15,16) 18: 1$, and decreased cis-13 16:1 + cis-15 16:1 in milk fat (Table 2 ). Changes in response to a higher proportion of concentrates were characterized by increases $(P<0.05)$ in cis-13 16:1 + cis-15 16:1 and cis-11 18:1, and decline $(P$ $<0.05)$ in cis-9 18:1 and cis-9 20:1. Amounts of specific MUFA induced by addition of SO were dependent on the dietary FC ratio. Increases in the proportions of trans-8 16:1 ( $\beta$-oxidation product of trans-10 18:1), cis13 18:1, trans- $6+7+8$ 18:1, and trans-10 18:1 in milk fat were higher when $\mathrm{SO}$ was included in the $\mathrm{H}$ than $\mathrm{L}$ 
treatment $(P<0.05$ for $\mathrm{FC} \times \mathrm{SO}$ interaction $)$, whereas the reverse was true for trans-9 16:1 ( $\beta$-oxidation product of trans-11 18:1), cis-12 18:1, and trans-11 18:1 ( $P$ $<0.05$ for $\mathrm{FC} \times \mathrm{SO}$ interaction). Furthermore, $\mathrm{SO}$ increased cis-9 16:1 when included in the $\mathrm{H}$ treatment, but decreased the proportion of this FA in milk on the $\mathrm{L}$ treatment $(P<0.05$ for $\mathrm{FC} \times \mathrm{SO}$ interaction $)$.

Proportions of certain 18:2 isomers in milk were affected by the FC ratio of the diet (Table 3 ). Changes in response to a higher proportion of concentrates were characterized by decreases $(P<0.01)$ in trans11,trans-15 18:2, trans-12,cis-15 18:2, trans-11,trans-13 CLA, and trans-12,trans-14 CLA. The SO supple-
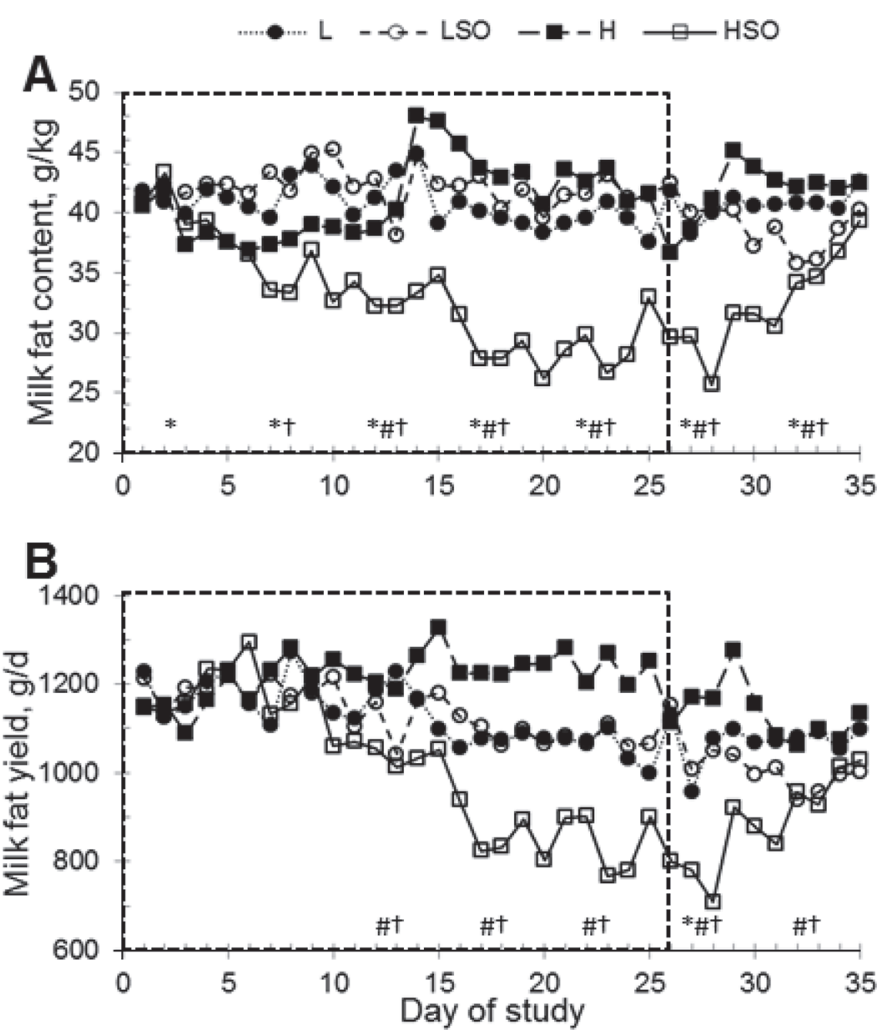

Figure 1. Temporal changes in milk fat content (A) and milk fat yield (B) of lactating cows in response to dietary forage to concentrate ratio (FC) and sunflower oil (SO). Treatments consisted of diets based on grass silage (FC ratio 65:35 and 35:65 on a DM basis, respectively) containing either 0 (treatments $\mathrm{L}$ and $\mathrm{H}$, respectively) or $50 \mathrm{~g} / \mathrm{kg}$ of diet DM of SO (treatments LSO and HSO, respectively). Cows were fed the experimental diets for $26 \mathrm{~d}$ (indicated by the dashed line square) followed by $9 \mathrm{~d}$ of washout. Symbols indicate the significance of effects $(P \leq 0.1)$ due to $\mathrm{FC} \times$ time interaction $(*)$, SO $\times$ time interaction $(\#)$, and $\mathrm{FC} \times \mathrm{SO} \times$ time interaction $(\dagger)$ in 5 -d intervals (d 1-5, d 6-10, d 11-15, d 16-20, d 21-25, d 26-30, and d 31-35). Significance of $\mathrm{FC} \times$ time, $\mathrm{SO} \times$ time, and $\mathrm{FC} \times \mathrm{SO} \times$ time interaction is $P=0.08, P<0.01$, and $P<0.01$, respectively, for milk fat content and $P=0.42, P<0.001$, and $P<0.001$, respectively, for milk fat yield. mentation increased the proportions of multiple 18:2 and CLA isomers in milk fat. The proportion of cis9,trans-12 18:2, cis-9,trans-14 18:2 + cis-7,cis-12 18:2, trans-9,cis-12 18:2, cis-9,cis-11 CLA, trans-7,cis-9 CLA, trans-8, cis-10 CLA, trans-8,trans-10 CLA, and trans-10,trans-12 CLA were increased $(P<0.05)$ by $\mathrm{SO}$. Including $\mathrm{SO}$ in the $\mathrm{H}$ treatment resulted in greater increases of cis-6,cis-12 18:2, cis-9,cis-12 18:2, cis9,trans-13 18:2 + cis-10,trans-14 18:2, trans-9,trans-12 18:2, trans-9,trans-13 18:2, trans-9,cis-11 CLA, trans10,cis-12 CLA proportions in milk fat compared with the supplementation of $\mathrm{L}$ treatment with $\mathrm{SO}(P<0.05$ for $\mathrm{FC} \times \mathrm{SO}$ interaction). In contrast, increases in cis9,trans-11 CLA were higher when SO was included in the $\mathrm{L}$ treatment $(P<0.05$ for $\mathrm{FC} \times \mathrm{SO}$ interaction $)$. Trans-12,cis-14 CLA in milk fat increased when SO was included in the $\mathrm{L}$ treatment, but decreased when $\mathrm{SO}$ was included in the $\mathrm{H}$ treatment $(P<0.05$ for $\mathrm{FC} \times$ $\mathrm{SO}$ interaction). Decline in the proportions of trans11,cis-13 CLA in milk fat were greater when SO was included in the $\mathrm{L}$ than $\mathrm{H}$ treatment $(P<0.05$ for $\mathrm{FC}$ $\times \mathrm{SO}$ interaction). The SO increased trans-11,cis-15 18:2 when included in the $\mathrm{H}$ treatment, but decreased the proportion of this $\mathrm{FA}$ in milk on the $\mathrm{L}$ treatment $(P<0.05$ for $\mathrm{FC} \times \mathrm{SO}$ interaction $)$. Trans-10, cis-15 18:2 was present only in milk from the HSO treatment. Both dietary FC ratio and SO supplement resulted in relatively minor changes in the proportions of odd- and branched-chain FA and FA containing oxo group in the milk fat (Supplemental Table S1; https://doi.org/10 $.3168 /$ jds.2018-15860).

Concentrate level by SO supplementation by time interaction over the 35-d experimental periods was significant $(P<0.05)$ for 4:0 and trans-10, cis-12 CLA (Figure $2)$. Temporal changes in milk FA composition revealed that reductions in proportions of 4:0 on HSO treatment were evident within $6 \mathrm{~d}$ and continued to decrease until the end of dietary treatment period (Figure 2A). The proportion of 16:0 in milk decreased after 3 and $4 \mathrm{~d}$ on treatments containing SO (Figure 2B). Similar but less pronounced changes for $\mathrm{SO}$ supplementation were observed in the proportions of 12:0 and 14:0, whereas they increased on the $\mathrm{H}$ treatment compared with the $\mathrm{L}$ treatment (Supplemental Figure S2A and S2B; https:/ /doi.org/10.3168/jds.2018-15860). The increase in 18:0 was more evident on the LSO than HSO treatment, starting after d 6 on HSO treatment (Figure 2C). The BH intermediates trans-10 18:1, trans-10, cis-12 CLA and trans-9,cis-11 CLA started to increase progressively on HSO treatment and reached maximum concentrations on d 17 to 19 (Figure 2D, 2E, and 2F). Trans-11 18:1 and cis-9,trans-11 CLA increased immediately after the addition of SO by d 3, but started to decline 
Table 1. Effect of dietary forage to concentrate ratio and sunflower oil on selected fatty acids in milk of lactating cows ${ }^{1}$

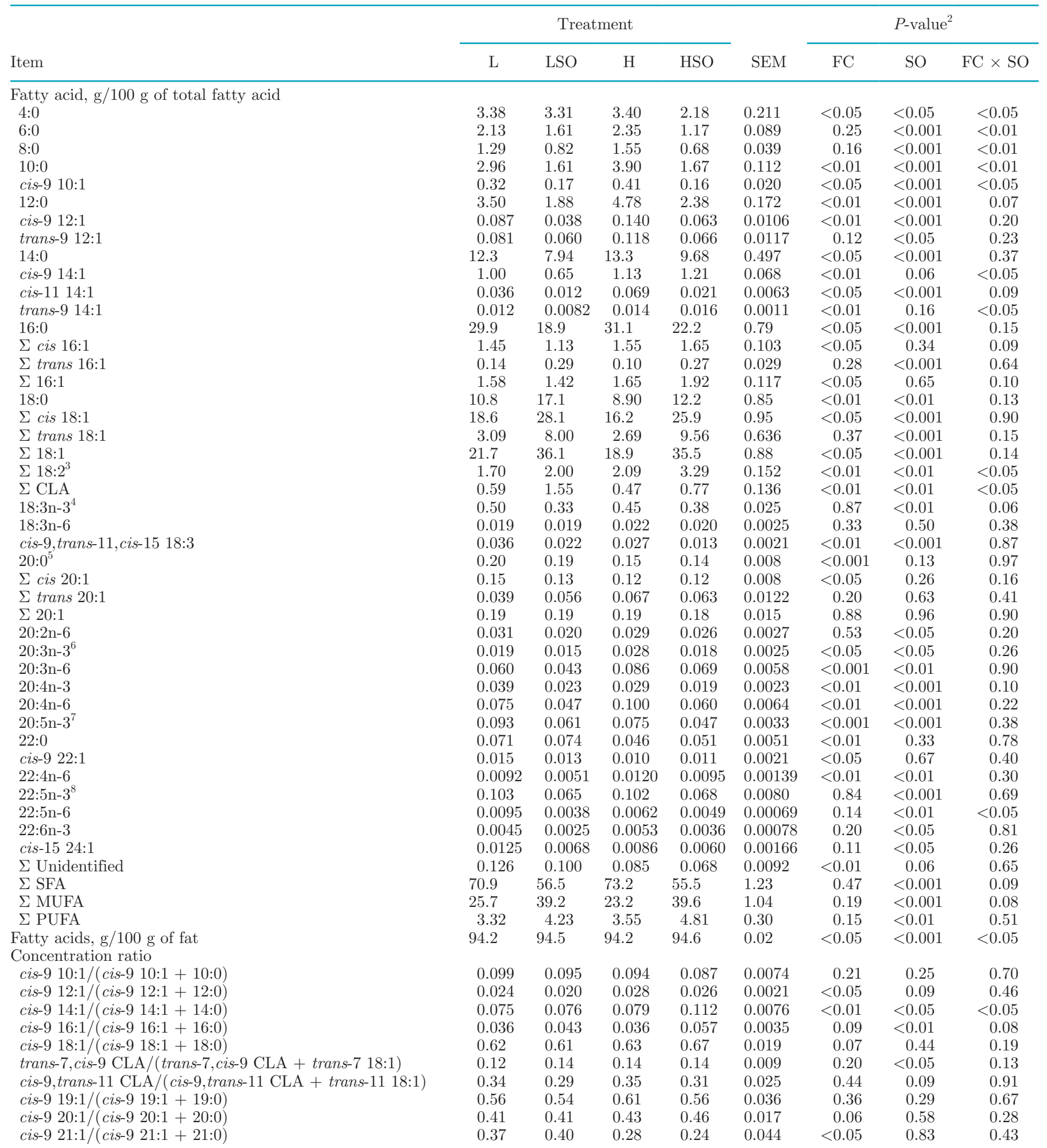


Table 1 (Continued). Effect of dietary forage to concentrate ratio and sunflower oil on selected fatty acids in milk of lactating cows ${ }^{1}$

\begin{tabular}{|c|c|c|c|c|c|c|c|c|}
\hline Item & \multicolumn{4}{|c|}{ Treatment } & SEM & \multicolumn{3}{|c|}{$P$-value ${ }^{2}$} \\
\hline cis-9 22:1/(cis-9 22:1 + 22:0) & 0.17 & 0.15 & 0.18 & 0.17 & 0.013 & 0.13 & 0.06 & 0.42 \\
\hline
\end{tabular}

${ }^{1}$ Values are LSM and pooled SEM, $\mathrm{n}=16$. Values represent the mean over d 22 to 25 of each experimental period. $\mathrm{FC}=$ forage to concentrate $\mathrm{L}=$ low concentrate diet (FC ratio 65:35 on a DM basis) with no additional lipid; LSO = low concentrate diet (FC ratio 65:35) containing 50 $\mathrm{g}$ of sunflower oil $/ \mathrm{kg}$ of diet $\mathrm{DM} ; \mathrm{H}=$ high concentrate diet (FC ratio 35:65) with no additional lipid; HSO = high concentrate diet (FC ratio 35:65) containing $50 \mathrm{~g}$ of sunflower oil $/ \mathrm{kg}$ of diet $\mathrm{DM} ; \mathrm{SO}=$ sunflower oil.

${ }^{2}$ Significance of effects due to dietary forage to concentrate ratio (FC), supplements of sunflower oil (SO), and their interaction $(\mathrm{FC} \times \mathrm{SO})$.

${ }^{3}$ Nonconjugated.

${ }^{4}$ Co-elutes with trans-15 20:1, trans-16 20:1, and cis-11 20:1.

${ }^{5}$ Co-elutes with unidentified fatty acid.

${ }^{6}$ Co-elutes with cis-13 22:1.

${ }^{7}$ Co-elutes with 24:0.

${ }^{8}$ Co-elutes with 26:0.

Table 2. Effect of dietary forage to concentrate ratio and sunflower oil on 16:1, 18:1, and 20:1 fatty acid composition in milk of lactating cows ${ }^{1}$

\begin{tabular}{|c|c|c|c|c|c|c|c|c|}
\hline $\begin{array}{l}\text { Fatty acid, } \mathrm{g} / 100 \mathrm{~g} \\
\text { of total fatty acid }\end{array}$ & \multicolumn{4}{|c|}{ Treatment } & SEM & \multicolumn{3}{|c|}{$P$-value ${ }^{2}$} \\
\hline cis- $6+716: 1^{3}$ & 0.17 & 0.20 & 0.16 & 0.22 & 0.011 & 0.88 & $<0.01$ & 0.29 \\
\hline cis-9 $16: 1$ & 1.12 & 0.86 & 1.15 & 1.35 & 0.085 & $<0.05$ & 0.71 & $<0.05$ \\
\hline cis-10 16:1 & 0.014 & 0.024 & 0.016 & 0.022 & 0.0017 & 0.92 & $<0.01$ & 0.24 \\
\hline cis-13 $16: 1^{4}$ & 0.145 & 0.043 & 0.227 & 0.069 & 0.0189 & $<0.05$ & $<0.001$ & 0.18 \\
\hline trans $-6+716: 1$ & 0.033 & 0.038 & 0.027 & 0.039 & 0.0028 & 0.23 & $<0.01$ & 0.11 \\
\hline trans-12 16:1 & 0.018 & 0.014 & 0.012 & 0.012 & 0.0010 & $<0.01$ & $<0.05$ & $<0.05$ \\
\hline trans-13 16:1 & 0.015 & 0.023 & 0.014 & 0.024 & 0.0018 & 0.83 & $<0.001$ & 0.17 \\
\hline cis-9 $18: 1^{5}$ & 17.7 & 26.7 & 15.2 & 24.4 & 0.93 & $<0.05$ & $<0.001$ & 0.91 \\
\hline cis-11 18:1 & 0.51 & 0.49 & 0.61 & 0.69 & 0.032 & $<0.01$ & 0.35 & 0.15 \\
\hline cis-12 18:1 & 0.18 & 0.52 & 0.25 & 0.40 & 0.028 & 0.37 & $<0.001$ & $<0.05$ \\
\hline cis-13 18:1 & 0.076 & 0.132 & 0.084 & 0.209 & 0.0076 & $<0.01$ & $<0.001$ & $<0.01$ \\
\hline cis-15 18:1 & 0.097 & 0.104 & 0.075 & 0.126 & 0.0100 & 0.99 & $<0.05$ & 0.07 \\
\hline trans-10 18:1 & 0.25 & 0.98 & 0.31 & 4.87 & 0.537 & $<0.01$ & $<0.01$ & $<0.05$ \\
\hline trans-11 18:1 & 1.14 & 3.23 & 0.71 & 0.83 & 0.201 & $<0.001$ & $<0.01$ & $<0.01$ \\
\hline trans-12 18:1 & 0.25 & 0.72 & 0.26 & 0.71 & 0.032 & 0.96 & $<0.001$ & 0.58 \\
\hline trans-13 18:1 & 0.38 & 0.65 & 0.38 & 0.79 & 0.037 & 0.10 & $<0.001$ & 0.11 \\
\hline trans-15 18:1 & 0.32 & 0.66 & 0.32 & 0.57 & 0.036 & 0.26 & $<0.001$ & 0.28 \\
\hline trans-16 $18: 1^{7}$ & 0.27 & 0.56 & 0.27 & 0.46 & 0.026 & 0.06 & $<0.001$ & 0.09 \\
\hline cis-9 20:1 & 0.14 & 0.13 & 0.11 & 0.11 & 0.008 & $<0.01$ & 0.28 & 0.22 \\
\hline trans-9-12 20:1 & 0.028 & 0.041 & 0.053 & 0.052 & 0.0102 & 0.13 & 0.59 & 0.53 \\
\hline trans-13 20:1 & 0.011 & 0.015 & 0.015 & 0.015 & 0.0020 & 0.93 & 0.89 & 0.09 \\
\hline
\end{tabular}

${ }^{1}$ Values are LSM and pooled SEM, $\mathrm{n}=16$. Values represent the mean over d 22 to 25 of each experimental period. $\mathrm{FC}=$ forage to concentrate; $\mathrm{L}=$ low concentrate diet (FC ratio $65: 35$ on a DM basis) with no additional lipid; LSO = low concentrate diet (FC ratio 65:35) containing 50 $\mathrm{g}$ of sunflower oil $/ \mathrm{kg}$ of diet $\mathrm{DM} ; \mathrm{H}=$ high concentrate diet (FC ratio 35:65) with no additional lipid; HSO = high concentrate diet (FC ratio 35:65) containing $50 \mathrm{~g}$ of sunflower oil $/ \mathrm{kg}$ of diet $\mathrm{DM} ; \mathrm{SO}=$ sunflower oil.

${ }^{2}$ Significance of effects due to dietary forage to concentrate ratio (FC), supplements of sunflower oil (SO), and their interaction $(\mathrm{FC} \times \mathrm{SO})$.

${ }^{3}$ Co-elutes with trans-11 16:1.

${ }^{4}$ Co-elutes with cis-15 16:1.

${ }^{5}$ Co-elutes with trans-14 18:1.

${ }^{6}$ Co-elutes with cis-8, cis-12 18:2.

${ }^{7}$ Co-elutes with cis-14 18:1. 
rapidly on d 5 on $\mathrm{HSO}$ while staying higher on LSO (Figure $2 \mathrm{G}$ and $2 \mathrm{H}$ ).

The SO supplementation increased $(P<0.05)$ the product/(product + substrate) concentration ratios cis-9 16:1/(cis-9 16:1 + 16:0) and trans-7,cis-9 CLA/ (trans-7,cis-9 CLA + trans-7 18:1) in milk (Table 1). Changes in response to a higher proportion of concentrates were characterized by increases $(P<0.05)$ in cis9 12:1/(cis-9 12:1 + 12:0) and decrease in cis-9 21:1/ (cis-9 21:1 + 21:0). Increases in the cis-9 14:1/(cis-9 14:1 + 14:0) were greater when SO was included in the $\mathrm{H}$ treatment than $\mathrm{L}$ treatment $(P<0.05$ for $\mathrm{FC} \times \mathrm{SO}$ interaction) and were close to significant for cis-9 16:1/ (cis-9 16:1 + 16:0; $P=0.08)$.
Across all treatments the negative relationship between milk fat yield and secretion of trans-10 18:1 in milk $(P<0.05)$ was weaker than the negative relationship between milk fat yield and flow of trans-10 18:1 at the omasum $(P<0.01$; Table 4$)$. On the contrary, the negative association between milk fat yield and flow of trans-9,cis-11 CLA at the omasum $(P=0.08)$ was weaker than the relationship between milk fat yield and secretion of trans-9,cis-11 CLA in milk $(P<0.05)$. A close linear relationship existed between the flow at the omasum and secretion in milk for trans-10 18:1, trans-11 18:1, 18:2n-6, trans-11,cis-15 18:2 and trans9,cis-11 CLA $(P<0.05)$, but not for trans-10,cis-12 CLA $(P=0.09$; Table 4$)$. Secretions of selected FA in

Table 3. Effect of dietary forage to concentrate ratio and sunflower oil on 18:2 fatty acid composition in milk of lactating cows ${ }^{1}$

\begin{tabular}{|c|c|c|c|c|c|c|c|c|}
\hline \multirow[b]{2}{*}{ Fatty acid } & \multicolumn{4}{|c|}{ Treatment } & \multirow[b]{2}{*}{ SEM } & \multicolumn{3}{|c|}{$P$-value ${ }^{2}$} \\
\hline & $\mathrm{L}$ & LSO & $\mathrm{H}$ & $\mathrm{HSO}$ & & $\mathrm{FC}$ & $\mathrm{SO}$ & $\mathrm{FC} \times \mathrm{SO}$ \\
\hline \multicolumn{9}{|c|}{ Nonconjugated $18: 2, \mathrm{~g} / 100 \mathrm{~g}$ of total fatty acid } \\
\hline cis-6, $6 i s-12 \quad 18: 2$ & 0.015 & 0.019 & 0.017 & 0.042 & 0.0031 & $<0.01$ & $<0.01$ & $<0.01$ \\
\hline cis-9,cis-12 $18: 2^{3}$ & 1.05 & 1.09 & 1.58 & 2.24 & 0.118 & $<0.001$ & $<0.05$ & $<0.05$ \\
\hline cis- 12, cis- $1518: 2^{4}$ & 0.028 & 0.028 & 0.044 & 0.030 & 0.0175 & 0.59 & 0.66 & 0.67 \\
\hline cis-9,trans-12 18:2 & 0.026 & 0.051 & 0.031 & 0.062 & 0.0047 & 0.11 & $<0.001$ & 0.48 \\
\hline cis-9,trans-13 18:2 $2^{5}$ & 0.15 & 0.32 & 0.14 & 0.38 & 0.020 & 0.10 & $<0.001$ & $<0.05$ \\
\hline cis-9,trans-14 18:2 $2^{6}$ & 0.079 & 0.143 & 0.073 & 0.164 & 0.0092 & 0.26 & $<0.001$ & 0.06 \\
\hline trans-9,cis-12 18:2 & 0.028 & 0.040 & 0.026 & 0.045 & 0.0021 & 0.47 & $<0.001$ & 0.15 \\
\hline trans-10,cis-15 18:2 & 0.000 & 0.000 & 0.000 & 0.017 & 0.0045 & 0.11 & 0.11 & 0.11 \\
\hline trans-11,cis-15 18:2 & 0.176 & 0.116 & 0.067 & 0.087 & 0.0112 & $<0.001$ & 0.13 & $<0.05$ \\
\hline trans-12,cis-15 18:2 & 0.024 & 0.019 & 0.018 & 0.017 & 0.0015 & $<0.05$ & 0.08 & 0.21 \\
\hline trans-9,trans-12 18:2 & 0.015 & 0.021 & 0.013 & 0.028 & 0.0014 & $<0.05$ & $<0.001$ & $<0.01$ \\
\hline trans-9,trans-13 18:2 & 0.023 & 0.064 & 0.027 & 0.088 & 0.0016 & $<0.01$ & $<0.001$ & $<0.001$ \\
\hline trans-10,trans-14 18:2 & 0.041 & 0.056 & 0.042 & 0.067 & 0.0104 & 0.62 & 0.10 & 0.66 \\
\hline trans-11,trans-15 18:2 & 0.043 & 0.044 & 0.017 & 0.019 & 0.0014 & $<0.001$ & 0.37 & 0.96 \\
\hline \multicolumn{9}{|c|}{ Conjugated $18: 2, \mathrm{mg} / 100 \mathrm{~g}$ of total fatty acid } \\
\hline cis-9,cis-11 CLA & 0.92 & 2.72 & 1.58 & 2.50 & 0.418 & 0.61 & $<0.05$ & 0.33 \\
\hline cis-9,trans-11 CLA & 468 & 1,332 & 360 & 494 & 133 & $<0.01$ & $<0.01$ & $<0.05$ \\
\hline cis-11,trans-13 CLA & 1.59 & 1.93 & 1.60 & 2.31 & 0.404 & 0.64 & 0.24 & 0.66 \\
\hline cis-12,trans-14 CLA & 1.50 & 1.52 & 1.18 & 2.48 & 0.409 & 0.46 & 0.16 & 0.17 \\
\hline trans-6,cis-8 CLA & 0.00 & 1.84 & 0.62 & 2.11 & 0.870 & 0.58 & 0.07 & 0.82 \\
\hline trans-7,cis-9 CLA & 31.0 & 97.5 & 33.3 & 117.6 & 5.69 & 0.05 & $<0.001$ & 0.11 \\
\hline trans-8,cis-10 CLA & 2.43 & 6.48 & 2.20 & 4.89 & 1.369 & 0.52 & $<0.05$ & 0.63 \\
\hline trans-9,cis-11 CLA & 9.04 & 21.0 & 10.0 & 68.5 & 4.969 & $<0.01$ & $<0.001$ & $<0.01$ \\
\hline trans-10,cis-12 CLA & 3.29 & 7.82 & 3.96 & 25.3 & 2.69 & $<0.05$ & $<0.01$ & $<0.05$ \\
\hline trans-11,cis-13 CLA & 24.0 & 11.9 & 5.56 & 3.43 & 1.626 & $<0.001$ & $<0.01$ & $<0.05$ \\
\hline trans-12,cis-14 CLA & 4.61 & 4.73 & 4.55 & 1.95 & 0.432 & $<0.05$ & $<0.05$ & $<0.05$ \\
\hline trans-7,trans-9 CLA & 4.85 & 4.10 & 4.54 & 2.99 & 0.748 & 0.35 & 0.15 & 0.58 \\
\hline trans-8,trans-10 CLA & 3.06 & 5.41 & 2.57 & 6.39 & 0.558 & 0.67 & $<0.01$ & 0.23 \\
\hline trans-9,trans-11 CLA & 12.3 & 18.4 & 13.2 & 9.51 & 2.188 & 0.10 & 0.57 & 0.05 \\
\hline trans-10,trans-12 CLA & 3.94 & 11.7 & 5.22 & 11.4 & 1.112 & 0.62 & $<0.001$ & 0.41 \\
\hline trans-11,trans-13 CLA & 13.6 & 11.6 & 9.63 & 7.67 & 1.362 & $<0.01$ & 0.09 & 0.98 \\
\hline trans-12,trans-14 CLA & 8.87 & 8.22 & 5.63 & 4.53 & 0.907 & $<0.01$ & 0.36 & 0.80 \\
\hline trans-13,trans-15 CLA & 1.01 & 0.99 & 0.80 & 1.34 & 0.288 & 0.81 & 0.41 & 0.36 \\
\hline
\end{tabular}

${ }^{1}$ Values are LSM and pooled SEM, $\mathrm{n}=16$. Values represent the mean over d 22 to 25 of each experimental period. FC $=$ forage to concentrate; $\mathrm{L}=$ low concentrate diet (FC ratio 65:35 on a DM basis) with no additional lipid; LSO $=$ low concentrate diet (FC ratio 65:35) containing 50 $\mathrm{g}$ of sunflower oil $/ \mathrm{kg}$ of diet DM; H = high concentrate diet (FC ratio 35:65) with no additional lipid; HSO = high concentrate diet (FC ratio 35:65) containing $50 \mathrm{~g}$ of sunflower oil $/ \mathrm{kg}$ of diet DM; $\mathrm{SO}=$ sunflower oil.

${ }^{2}$ Significance of effects due to dietary forage to concentrate ratio $(\mathrm{FC})$, supplements of sunflower oil $(\mathrm{SO})$, and their interaction $(\mathrm{FC} \times \mathrm{SO})$.

${ }^{3}$ Contains cis-9, cis-15 $18: 2$ as a minor component.

${ }^{4}$ Co-elutes with unidentified fatty acid.

${ }^{5}$ Co-elutes with cis-10,trans-14 18:2.

${ }^{6}$ Co-elutes with cis-7, cis-12 18:2. 


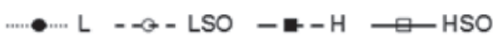

A

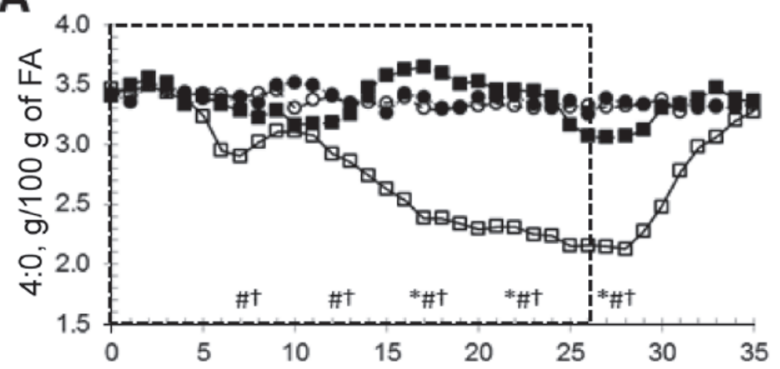

C

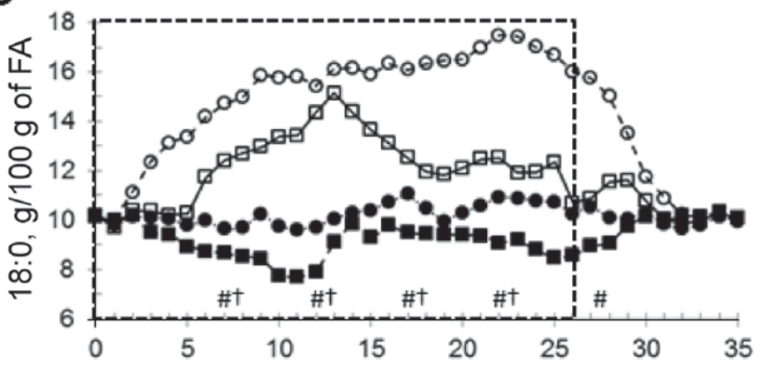

E

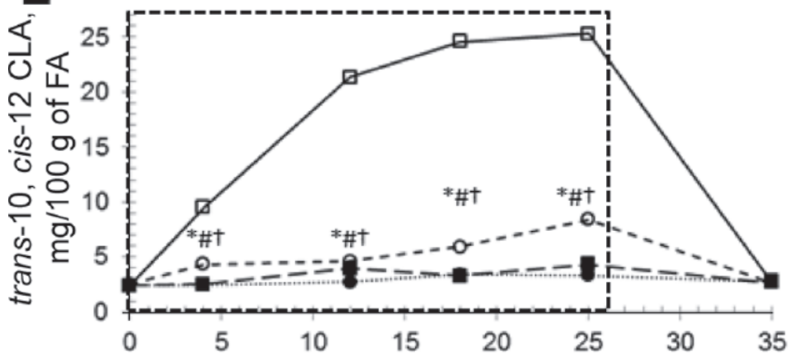

G

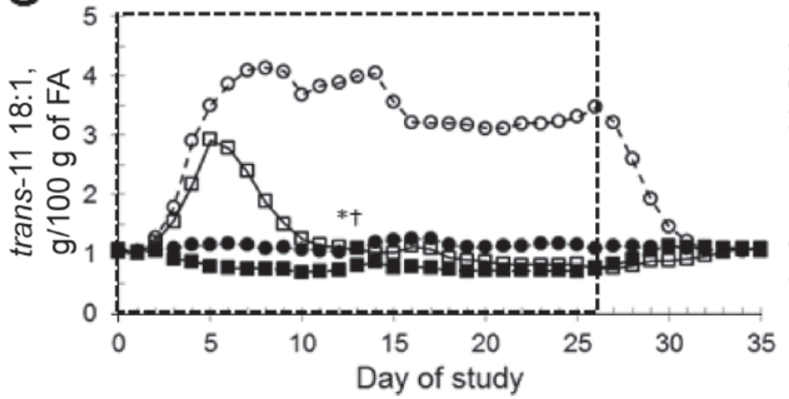

B
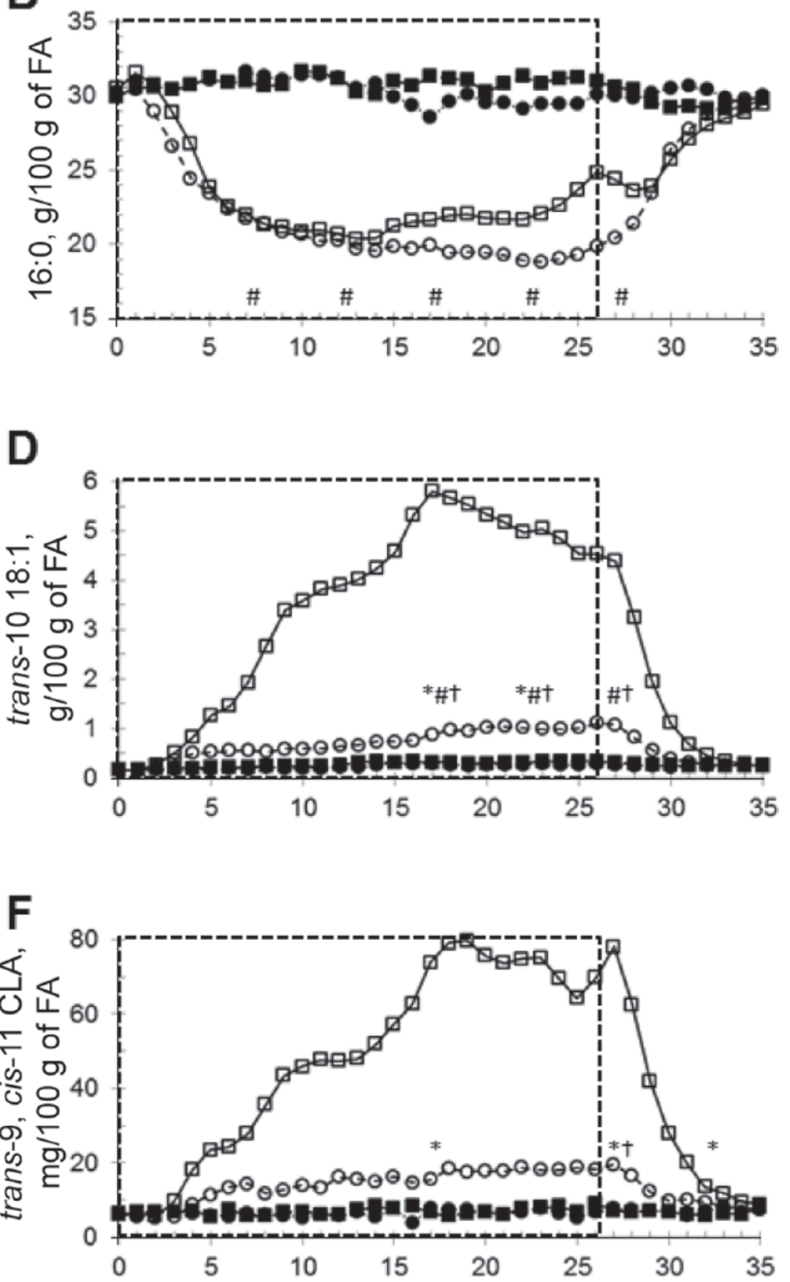

H

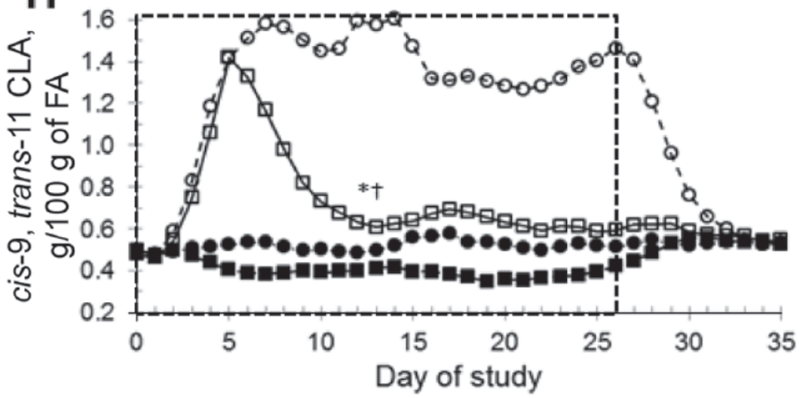

Figure 2. Temporal changes in the proportion of 4:0 (A), 16:0 (B), 18:0 (C), trans-10 18:1 (D), trans-10, cis-12 CLA (E), trans-9, cis-11 CLA (F), trans-11 18:1 (G), and cis-9,trans-11 CLA (+ trans-7,cis-9 CLA and trans-8,cis-10 CLA as minor components; H) in milk of lactating cows in response to dietary forage to concentrate ratio (FC) and sunflower oil (SO). Treatments consisted of diets based on grass silage (FC ratio 65:35 and 35:65 on a DM basis, respectively) containing either 0 (treatments L and H, respectively) or $50 \mathrm{~g} / \mathrm{kg}$ of diet DM of SO (treatments LSO and HSO, respectively). Cows were fed the experimental diets for $26 \mathrm{~d}$ (indicated by the dashed line square) followed by $9 \mathrm{~d}$ of washout. Symbols indicate the significance of effects $(P \leq 0.1)$ due to $\mathrm{FC} \times$ time interaction $\left.{ }^{*}\right)$, SO $\times$ time interaction $(\#)$, and $\mathrm{FC} \times \mathrm{SO} \times$ time interaction $(\dagger)$ in 5-d intervals (d 1-5, d 6-10, d 11-15, d 16-20, d 21-25, d 26-30, and d 31-35). Significance of FC $\times$ time, SO $\times$ time, and FC $\times$ SO $\times$ time interaction is $P<0.001, P=0.08$, and $P<0.05$, respectively, for 4:0; $P=0.94, P=0.09$, and $P=0.93$, respectively, for $16: 0 ; P=0.90, P<$ 0.001 , and $P=0.32$, respectively, for 18:0; $P=0.22, P=0.15$, and $P=0.33$, respectively, for trans-10 $18: 1 ; P<0.001, P<0.001$, and $P<$ 0.001 , respectively, for trans-10, cis-12 CLA; $P=0.23, P=0.83$, and $P=0.61$, respectively, for trans-9, cis-11 CLA; $P=0.13, P=0.87$, and $P$ $=0.15$, respectively, for trans-11 $18: 1$; and $P=0.23, P=0.83$, and $P=0.28$, respectively, for cis-9,trans-11 CLA. FA $=$ fatty acids 
Table 4. Relationship between the flow of selected fatty acids at the omasum, the secretion of selected fatty acids in milk, and milk fat yield in lactating cows fed diets of different forage to concentrate ratio with or without sunflower oil ${ }^{1}$

\begin{tabular}{|c|c|c|c|c|c|c|c|c|}
\hline $\begin{array}{l}\text { Independent variable } \\
(\mathrm{X})\end{array}$ & $\begin{array}{l}\text { Dependent variable } \\
(\mathrm{Y})\end{array}$ & Intercept & $\mathrm{SE}$ & $P$-value & Slope & $\mathrm{SE}$ & $\mathrm{r}_{\text {adj }}^{2}$ & $P$-value \\
\hline Omasal flow, g/d & Milk fat yield, $\mathrm{g} / \mathrm{d}$ & & & & & & & \\
\hline trans-10, cis-12 CLA & & 1,100 & 99.6 & $<0.001$ & -127 & 197 & -0.04 & 0.53 \\
\hline trans-10, cis-15 18:2 & & 1,040 & 188 & $<0.05$ & -87.5 & 62.80 & 0.24 & $0.30^{3}$ \\
\hline Secretion in milk, g/d & Milk fat yield, $\mathrm{g} / \mathrm{d}$ & & & & & & & \\
\hline trans-10,cis-12 CLA & & 1,160 & 86.0 & $<0.001$ & $-1,283$ & 766 & 0.17 & 0.12 \\
\hline trans-10, cis-15 18:2 & & 1,078 & 227 & $<0.05$ & $-2,192$ & 1,734 & 0.17 & $0.33^{3}$ \\
\hline Omasal flow, $\mathrm{g} / \mathrm{d}$ & $\begin{array}{l}\text { Secretion in milk, } \mathrm{g} / \mathrm{d} \\
\text { unless otherwise indicated }\end{array}$ & & & & & & & \\
\hline trans-10 18:1 & trans-8 16:1, mg/d & 85.4 & 30.30 & $<0.05$ & 5.71 & 0.420 & 0.92 & $<0.001$ \\
\hline trans-10 18:1 & trans-10 18:1 & 4.09 & 1.865 & $<0.05$ & 0.22 & 0.026 & 0.82 & $<0.001$ \\
\hline trans-11 18:1 & trans-11 18:1 & 1.91 & 2.103 & 0.38 & 0.27 & 0.035 & 0.80 & $<0.001$ \\
\hline
\end{tabular}

${ }^{1}$ Linear regressions derived using individual results, $\mathrm{n}=16$.

${ }^{2}$ Adjusted coefficient of determination.

${ }^{3}$ Only 4 observations from HSO treatment $[\mathrm{HSO}=$ high concentrate diet (forage to concentrate ratio 35:65) containing $50 \mathrm{~g}$ of sunflower oil/kg of diet $\mathrm{dm}]$. No observations for other treatments.

milk are shown in Supplemental Table S2 (https://doi .org/10.3168/jds.2018-15860).

\section{DISCUSSION}

Diets containing both high proportion of concentrates and PUFA decrease milk fat content and yield, representing a typical response called diet-induced MFD in lactating cows (Bauman and Griinari, 2003; Shingfield and Griinari, 2007; Harvatine et al., 2009). Even though changes in milk fat composition and secretion on low-fiber, high-oil diets have been characterized (Griinari et al., 1998; Peterson et al., 2003; Roy et al., 2006; Rico and Harvatine, 2013), a direct cause and effect of diet-induced MFD has not been established and studies investigating the temporal changes in the onset and recovery from MFD are scarce.

Inclusion of SO in the high-concentrate diet induced a decline in milk fat content by $7 \mathrm{~d}$, but decreased fat secretion by $17 \mathrm{~d}$. The explanation to this discrepancy is the rapid increase in milk yield immediately after the start of high-concentrate treatments resulting in unchanged fat secretion. The increased milk yield may also have induced a dilution effect on milk fat content on $\mathrm{HSO}$ and $\mathrm{H}$ and on protein content on $\mathrm{HSO}$ by d 7 (Supplemental Figure S1B; https://doi.org/10 .3168/jds.2018-15860). However, the decline in milk fat content on HSO after $\mathrm{d} 7$ is most likely an effect of
MFD, because the protein content on HSO was normalized and then increased and the decrease in milk fat content became more pronounced on HSO than $\mathrm{H}$. Overall, HSO treatment lowered milk fat synthesis from -20.2 to $-31.9 \%$ relative to other treatments without negative effects on total DMI (19.0, 18.6, 23.3, and 20.7 $\mathrm{kg} / \mathrm{d}$ for $\mathrm{L}, \mathrm{LSO}, \mathrm{H}$, and HSO, respectively; Ventto et al., 2017). The magnitude of MFD on the HSO treatment was within the expected range reported earlier for lactating cows (Bauman and Griinari, 2003; Shingfield and Griinari, 2007; Harvatine et al., 2009).

The milk fat lowering response on HSO occurred in 2 stages. On d 5 to 7 a turning point occurred in which milk yield and proportions of trans-11 18:1 and cis9,trans-11 CLA in milk fat on HSO reached the highest values and after that started to decrease. Milk yield on $\mathrm{HSO}$ and $\mathrm{H}$ followed a similar temporal trend, but contrary to HSO, trans-11 18:1 and cis-9,trans-11 CLA continued to increase on LSO. At the same time point (d 5 to 7 ), milk fat content and proportion of 4:0 reached lower values. In addition, the proportion of 18:0 in milk fat on HSO started to increase after that time point. A second turning point on HSO was observed on d 15 to 17 in which another drop in milk fat content was observed and milk fat yield reached lower values. After this, the response in milk fat content and yield reached a plateau. Furthermore, at this time point the proportions of trans-10 18:1, trans-9,cis-11 CLA, and trans- 
10,cis-12 CLA in milk fat on HSO reached the highest values, whereas the reverse was true for 4:0. After this time point a gradual increasing trend was observed for 16:0, and the proportion of 18:0 reached a plateau after a decrease from the highest values observed in $\mathrm{d} 13$.

The BH theory of diet-induced MFD (Bauman and Griinari, 2001) attributes the inhibition of milk fat synthesis to changes in ruminal lipid metabolism and increased formation of specific $\mathrm{BH}$ intermediates. Trans10, cis-12 CLA is the only intermediate that is known unequivocally to lower milk fat synthesis in lactating cows (Baumgard et al., 2000; Bauman and Griinari, 2003), with evidence that cis-10,trans-12 CLA (Saeb $\varnothing$ et al., 2005) and trans-9,cis-11 CLA (Perfield et al., 2007) may also act as a possible inhibitor. Under the conditions of this experiment, an increase in the omasal flow of trans-10, cis-12 CLA was observed on both $\mathrm{H}$ and HSO treatments, implying that other $\mathrm{BH}$ intermediates or mechanisms were contributing to the MFD (Ventto et al., 2017). The omasal flow of trans-9,cis-11 CLA on HSO was numerically higher but not statistically significantly affected by treatments (Ventto et al., 2017). Contrary to these observations, MFD on the HSO treatment was accompanied by an increase in both trans-10,cis-12 CLA and trans-9,cis-11 CLA in milk fat. The discrepancies in omasal and milk FA composition observed for trans-10,cis-12 CLA indicate that the mechanisms driving the progress of diet-induced MFD cannot be studied only by measuring specific FA BH intermediates in milk, but the omasal or duodenal flow of these FA available for absorption should also be taken into account and quantified. The unexpected difference between omasal flow and secretion in milk, especially in the case of trans-10,cis-12 CLA, could result from unique transfer pathways to milk. Urrutia et al. (2018) showed that trans-10,cis-12 CLA was transferred to milk fat at a lower rate than cis-9,trans-11 CLA when both CLA isomers were administered as equal abomasal bolus infusions to dairy cows. Compartmental modeling indicated that cis-9,trans-11 CLA and trans-10,cis-12 CLA are processed differently and that trans-10,cis-12 CLA is partly transferred to a transiently unavailable pool in extravascular tissues (primarily mammary gland) and slowly recycles to the available pool for milk fat synthesis (Urrutia et al., 2018). Whether this kind of transiently unavailable pool exists for other $\mathrm{BH}$ intermediates such as trans-9, cis-11 CLA is not known. Because trans-10,cis-12 CLA at the omasum was increased also in non-MFD causing $\mathrm{H}$ treatment in the present study, we speculate that other FA or other contributing factors occurring due to the treatments might affect the absorption rate from the intestine, transport and metabolism, mammary uptake, bioactive properties, or transfer of trans-10,cis-12 CLA (or other
MFD causing BH intermediates) to milk. However, this speculation remains unresolved.

Even though inclusion of $\mathrm{SO}$ on $\mathrm{H}$ diet resulted in increased secretion of trans-10,cis-12 CLA in milk (Supplemental Table S2; https://doi.org/10.3168/jds .2018-15860), no association between milk fat yield and omasal flow or secretion of trans-10, cis-12 CLA in milk was observed. However, $26 \%$ of variation in milk fat yield can be explained by trans-9,cis-11 CLA secretion in milk, whereas for omasal flow of trans-9, cis-11 CLA the coefficient of determination was $14 \%(P=0.08)$. This could be considered evidence that trans- 9 , cis-11 CLA but not trans-10,cis-12 CLA is involved in the onset and progress of MFD in the present study. The previously reported postruminal flows of trans-10, cis-12 CLA and concentrations of trans-10,cis-12 CLA in milk fat are lower than expected in diet-induced MFD when compared with studies where MFD was caused by trans-10, cis-12 CLA supplementation (Bauman and Griinari, 2003; Shingfield and Griinari, 2007; Glasser et al., 2010). Furthermore, FO-induced MFD has been shown not to be associated with increases in milk trans-10,cis-12 CLA (Loor et al., 2005a; Kairenius et al., 2015) or the amounts of trans-9,cis-11 CLA and trans-10, cis-12 CLA at the omasum (Kairenius et al., 2015). Because of the limited number of milk samples over time with detailed CLA profile analyses in the present study, we were not able to exactly identify the onset in the increase of trans-10,cis-12 CLA proportion or the time point for peak concentration. However, trans-10,cis-12 CLA in milk fat seems to follow the same temporal pattern observed for trans-10 18:1 and trans-9,cis-11 CLA albeit a more rapid increase in trans-10, cis-12 CLA.

Under normal conditions cis-9,trans-11 CLA is an intermediate product of the major $\mathrm{BH}$ pathway in the rumen (Shingfield et al., 2010). Even though cis-9,trans-11 CLA and trans-11 18:1 in milk fat were increased during SO supplementation until d 5, their amount was thereafter rapidly decreased when $\mathrm{SO}$ was included in the $\mathrm{H}$ but not $\mathrm{L}$ treatment, reflecting their flow at the omasum on d 22 to 24 (Ventto et al., 2017). Cis-9,trans-11 CLA is the main CLA isomer formed in the $\mathrm{BH}$ of $18: 2 \mathrm{n}-6$ in the rumen and it is also produced in the $\Delta^{9}$ desaturation of trans-11 18:1 in the mammary gland (Shingfield et al., 2010), which explains the identical responses in the proportion of cis-9,trans-11 CLA and trans-11 18:1 in milk fat. Previous studies have reported similar temporal shift from cis-9,trans-11 CLA and trans-11 18:1 formation to trans-10 18:1, trans-10,cis-12 CLA (Rico and Harvatine, 2013) and trans-9,cis-11 CLA formation (Roy et al., 2006; Shingfield et al., 2006) in milk fat on diet-induced MFD. In the present study, $\mathrm{SO}$ also induced an increase in 
cis-9,cis-11 CLA, trans-8,cis-10 CLA, trans-8,trans-10 CLA, and trans-10,trans-12 CLA in milk fat regardless of the amount of concentrate in the diet.

Supplementation of SO increased the proportion of total 18:1 isomers in milk fat. The HSO treatment caused a shift in $\mathrm{BH}$ pathways resulting in the formation of trans-10 18:1 in the rumen instead of trans-11 18:1, which was the major $\mathrm{BH}$ intermediate on LSO (Ventto et al., 2017). This was reflected in milk fat with increased proportions of trans-10 18:1 and trans-11 18:1 on HSO and LSO, respectively. The increased synthesis of trans-10 18:1 in the rumen is known to increase trans-10 18:1 in milk from cows fed diets causing MFD (Bauman and Griinari, 2003; Loor et al., 2005b; Roy et al., 2006; Rico and Harvatine, 2013). The evidence that trans-10 18:1 inhibits milk fat synthesis is inconsistent (Lock et al., 2007; Kadegowda et al., 2008), but the negative association between milk fat secretion and trans-10 18:1 flow at the omasum and secretion in milk in the present study support the theory that trans-10 18:1 has a role in the regulation of milk fat synthesis. In addition, the association between the flow at the omasum and secretion in milk for trans-10 18:1 was stronger than for trans-9,cis-11 CLA.

Decreased milk fat fluidity and increased milk fat melting point has been suggested to contribute to MFD, especially when cows are fed FO supplements, due to the increased amounts of trans 18:1 and decreased amounts of cis-9 18:1 in milk (Loor et al., 2005b; Gama et al., 2008). In the present experiment, SO lowered the calculated mean milk fat melting points, which could theoretically indicate increased milk fat fluidity. In addition, the concentration ratios cis-9 14:1/(cis-9 14:1 + 14:0) and cis-9 16:1/(cis-9 16:1 + 16:0) indicating stearoyl-CoA desaturase activity were inversely related to milk fat, confirming earlier reports (Gama et al., 2008; Rico and Harvatine, 2013). Even a considerable decrease in the $\Delta^{9}$ desaturation of FA in the mammary gland and an increase in calculated milk fat melting point caused by Co-EDTA did not affect milk fat content or output in lactating cows (Leskinen et al., 2016). Altogether these findings support the conclusion that a decrease in the availability of stearoyl-CoA desaturase products for milk fat synthesis and increasing milk fat melting point are not likely driving mechanisms in MFD (Shingfield and Griinari, 2007; Harvatine et al., 2009).

The content and yield of de novo synthesized FA $(<16$ carbons) in milk decrease during MFD (Peterson et al., 2003; Shingfield et al., 2006; Rico and Harvatine, 2013). In addition, inclusion of plant oils typically lowers the concentrations of short- and medium-chain FA ( $\leq 16$ carbons) in milk without the occurrence of MFD (Kliem and Shingfield, 2016). The proportion (g/100 g of FA) of de novo FA, 10:0, 12:0, and 14:0, and 16:0 in milk fat were decreased on oil-supplemented diets, but milk fat on the HSO contained proportionally more of these FA than milk fat on LSO (see also Supplemental Figure S2; https://doi.org/10.3168/jds.2018-15860), and the outputs (g/d; Supplemental Table S2; https:// doi.org/10.3168/jds.2018-15860) of these FA in milk on d 22 to 25 were not different between LSO and HSO. The inclusion of SO in the diets induced a rapid decline in 16:0, indicating a quick response in de novo FA synthesis, but contrary to LSO, the proportion of 16:0 on HSO had an increasing trend after d 15. Contrary to the expectations based on ruminal flow of 18:0 (Ventto et al., 2017), the proportion of 18:0 in milk fat did not increase in a similar manner on $\mathrm{HSO}$ as on LSO. On HSO, a lag of $5 \mathrm{~d}$ was observed before the gradual increase in 18:0, and a peak concentration in 18:0 abundance occurred on d 13, $2 \mathrm{~d}$ before the rapid drop in milk fat content and yield (d 15). This indicates that a reduction in the de novo synthesis has not been a key factor in MFD in the present study. A similar increasing-decreasing trend in the proportion of 18:0 was observed in an earlier study with high-concentrate diets supplemented with SO (Roy et al., 2006).

Supplementation of SO in the high-concentrate diet decreased the proportions of short-chain FA (4:0, 6:0, and 8:0) and their secretion in milk was lower on the HSO treatment compared with LSO (Supplemental Table S2; https://doi.org/10.3168/jds.2018-15860). The lowered incorporation of 4:0 in milk fat following the same temporal pattern as milk fat content may be a result of reduced utilization of 4:0 and BHB in TG synthesis or reduced synthesis of 4:0 from acetate in the mammary gland. The rumen VFA concentration and composition were not changed on HSO (Bayat et al., 2017) and cannot explain the differences observed in the proportions of short-chain FA in milk fat. Plasma metabolites were not analyzed in the present experiment, but earlier studies have reported changes in the mammary uptake (jugular-mammary venous differences) for BHB and acetate in cows fed FO (Loor et al., 2005a) and high-concentrate diets (Loor et al., 2005b). However, earlier reports suggest that the possible shifts in the rumen production of acetate and butyrate, the plasma acetate and BHB concentrations, mammary uptake of these metabolites, and reductions in de novo FA synthesis cannot fully explain diet-induced MFD (Bauman and Griinari, 2003; Loor et al., 2005b).

Flow of 18:2n-6 at the omasum was increased on $\mathrm{H}$ treatments compared with $\mathrm{L}$ treatments as a result of decreased ruminal BH (Ventto et al., 2017). Furthermore, the proportion of $18: 2 \mathrm{n}-6$ in milk fat and the output of 18:2n-6 in milk (Supplemental Table S2; https://doi.org/10.3168/jds.2018-15860) was higher on 
$\mathrm{H}$ treatments compared with $\mathrm{L}$ treatments, and a close linear relationship was observed between the flow at the omasum and secretion in milk for 18:2n-6. Intake of 18:3n- 3 and flow of $\mathrm{BH}$ products cis-9,trans-11, cis- 15 18:3, trans-11,cis-15 18:2, and trans-11,trans-15 18:2 at the omasum were higher on $\mathrm{L}$ than $\mathrm{H}$ treatments (Ventto et al., 2017) and this was reflected in milk fat resulting lower amounts of these $\mathrm{BH}$ products on $\mathrm{H}$ and HSO. Biohydrogenation product trans-10, cis-15 18:2 was only found in milk fat on HSO treatment providing more support to the existence of alternative trans-10 pathway of 18:3n-3 metabolism in the rumen (Alves and Bessa, 2014) that is pronounced in cows fed diets causing MFD.

\section{CONCLUSIONS}

The temporal changes in milk fat content, milk fat yield, and the proportions of MFD-related BH intermediates showed that the recovery from MFD was more rapid than the onset of MFD. Inclusion of SO in a highconcentrate diet induced a 2-stage drop in milk fat synthesis accompanied by specific changes in the milk FA composition over time. Biohydrogenation intermediates trans-10 18:1, trans-10,cis-12 CLA, and trans-9,cis-11 CLA in milk increased gradually during the progress of MFD, whereas cis-9,trans-11 CLA and trans-11 18:1 increased rapidly but declined subsequently at the onset of MFD, reflecting the shift from the predominant ruminal BH pathway to another pathway. Especially the flow of trans-10 18:1 at the omasum was associated with milk fat secretion across all treatments. In addition, increased proportions of trans-10,cis-15 18:2 in omasal digesta and milk fat were observed in MFD. The association of MFD with omasal and milk trans10, cis-12 CLA, an intermediate known to inhibit milk fat synthesis in the mammary gland, was ambiguous, suggesting that other ruminal BH intermediates or additional mechanisms contributed to the diet-induced MFD in dairy cows. To identify the effects of certain FA BH intermediates on MFD, FA infusion studies are needed to remove the effect of other confounding factors causing MFD.

\section{ACKNOWLEDGMENTS}

The authors dedicate this article to the memory of the late Professor Kevin Shingfield. This work was supported by the Finnish Ministry of Agriculture and Forestry, Helsinki, Finland, and Valio, Ltd., Helsinki, Finland. L. Ventto was a recipient of a PhD studentship from the Raisio Science Foundation, Raisio, Finland, and the August Johannes and Aino Tiura Agricultural Science Foundation, Helsinki, Finland. The authors gratefully acknowledge Minna Aalto and Tuija Hakala, Natural Resources Institute Finland (Luke), for help with lipid analyses.

\section{REFERENCES}

Alves, S. P., and R. J. B. Bessa. 2014. The trans-10,cis-15 18:2: A missing intermediate of trans-10 shifted rumen biohydrogenation pathway? Lipids 49:527-541.

Bauman, D. E., and J. M. Griinari. 2001. Regulation and nutritional manipulation of milk fat: Low-fat milk syndrome. Livest. Prod. Sci. 70:15-29.

Bauman, D. E., and J. M. Griinari. 2003. Nutritional regulation of milk fat synthesis. Annu. Rev. Nutr. 23:203-227.

Baumgard, L. H., B. A. Corl, D. A. Dwyer, A. Saebø, and D. E. Bauman. 2000. Identification of the conjugated linoleic acid isomer that inhibits milk fat synthesis. Am. J. Physiol. Regul. Integr. Comp. Physiol. 278:R179-R184.

Bayat, A. R., L. Ventto, P. Kairenius, T. Stefański, H. Leskinen, I. Tapio, E. Negussie, J. Vilkki, and K. J. Shingfield. 2017. Dietary forage to concentrate ratio and sunflower oil supplement alter rumen fermentation, ruminal methane emissions, and nutrient utilization in lactating cows. Transl. Anim. Sci. 1:277-286.

European Council. 1986. Council Directive of 24 November 1986 on the approximation of laws, regulations and administrative provisions of the Member States regarding the protection of animals used for experimental and other scientific purposes $(86 / 609 / \mathrm{EEC})$. Off. J. Eur. Communities L358:1-28.

Gama, M. A. S., P. C. Garnsworthy, J. M. Griinari, P. R. Leme, P. H. M. Rodrigues, L. W. O. Souza, and D. P. D. Lanna. 2008. Dietinduced milk fat depression: Association with changes in milk fatty acid composition and fluidity of milk fat. Livest. Sci. 115:319-331.

Glasser, F., A. Ferlay, M. Doreau, J. J. Loor, and Y. Chilliard. 2010. $t 10, c 12-18: 2$-Induced milk fat depression is less pronounced in cows fed high-concentrate diets. Lipids 45:877-887.

Griinari, J. M., D. A. Dwyer, M. A. McGuire, D. E. Bauman, D. L. Palmquist, and K. V. V. Nurmela. 1998. Trans-octadecenoic acids and milk fat depression in lactating dairy cows. J. Dairy Sci. 81:1251-1261.

Halmemies-Beauchet-Filleau, A., T. Kokkonen, A.-M. Lampi, V. Toivonen, K. J. Shingfield, and A. Vanhatalo. 2011. Effect of plant oils and camelina expeller on milk fatty acid composition in lactating cows fed diets based on red clover silage. J. Dairy Sci. 94:4413-4430.

Harvatine, K. J., and D. E. Bauman. 2011. Characterization of the acute lactational response to trans-10, cis-12 conjugated linoleic acid. J. Dairy Sci. 94:6047-6056.

Harvatine, K. J., Y. R. Boisclair, and D. E. Bauman. 2009. Recent advances in the regulation of milk fat synthesis. Animal 3:40-54.

Kadegowda, A. K. G., L. S. Piperova, and R. A. Erdman. 2008. Principal component and multivariate analysis of milk long-chain fatty acid composition during diet-induced milk fat depression. J. Dairy Sci. 91:749-759

Kairenius, P., A. Ärölä, H. Leskinen, V. Toivonen, S. Ahvenjärvi, A. Vanhatalo, P. Huhtanen, T. Hurme, J. M. Griinari, and K. J. Shingfield. 2015. Dietary fish oil supplements depress milk fat yield and alter milk fatty acid composition in lactating cows fed grass silage-based diets. J. Dairy Sci. 98:5653-5671.

Kliem, K. E., and K. J. Shingfield. 2016. Manipulation of milk fatty acid composition in lactating cows: Opportunities and challenges. Eur. J. Lipid Sci. Technol. 118:1661-1683.

Leskinen, H., S. Viitala, M. Mutikainen, P. Kairenius, I. Tapio, J. Taponen, L. Bernard, J. Vilkki, and K. J. Shingfield. 2016. Ruminal Infusions of cobalt EDTA modify milk fatty acid composition via decreases in fatty acid desaturation and altered gene expression in the mammary gland of lactating cows. J. Nutr. 146:976-985.

Lock, A. L., C. Tyburczy, D. A. Dwyer, K. J. Harvatine, F. Destaillats, Z. Mouloungui, L. Candy, and D. E. Bauman. 2007. Trans-10 octadecenoic acid does not reduce milk fat synthesis in dairy cows. J. Nutr. 137:71-76. 
Loor, J. J., M. Doreau, J. M. Chardigny, A. Ollier, J. L. Sebedio, and Y. Chilliard. 2005a. Effects of ruminal or duodenal supply of fish oil on milk fat secretion and profiles of trans-fatty acids and conjugated linoleic acid isomers in dairy cows fed maize silage. Anim. Feed Sci. Technol. 119:227-246.

Loor, J. J., A. Ferlay, A. Ollier, M. Doreau, and Y. Chilliard. 2005b. Relationship among trans and conjugated fatty acids and bovine milk fat yield due to dietary concentrate and linseed oil. J. Dairy Sci. 88:726-740.

Luke. 2018. Feed tables and nutrient requirements. Natural Resources Institute Finland (Luke). Accessed Jan. 2011. http://www.luke.fi/ feedtables.

Perfield, J. W., A. L. Lock, J. M. Griinari, A. Sæbø, P. Delmonte, D. A. Dwyer, and D. E. Bauman. 2007. Trans-9, cis-11 conjugated linoleic acid reduces milk fat synthesis in lactating dairy cows. J. Dairy Sci. 90:2211-2218.

Peterson, D. G., E. A. Matitashvili, and D. E. Bauman. 2003. Diet-induced milk fat depression in dairy cows results in increased trans-10, cis-12 CLA in milk fat and coordinate suppression of mRNA abundance for mammary enzymes involved in milk fat synthesis. J. Nutr. 133:3098-3102.

Rico, D. E., and K. J. Harvatine. 2013. Induction of and recovery from milk fat depression occurs progressively in dairy cows switched between diets that differ in fiber and oil concentration. J. Dairy Sci. 96:6621-6630.

Roy, A., A. Ferlay, K. J. Shingfield, and Y. Chilliard. 2006. Examination of the persistency of milk fatty acid composition responses to plant oils in cows given different basal diets, with particular emphasis on trans-C18:1 fatty acids and isomers of conjugated linoleic acid. Anim. Sci. 82:479-492.

Saebø, A., P. C. Saebø, J. M. Griinari, and K. J. Shingfield. 2005. Effect of abomasal infusions of geometric isomers of 10,12 conjugated linoleic acid on milk fat synthesis in dairy cows. Lipids 40:823-832.

Shingfield, K. J., S. Ahvenjärvi, V. Toivonen, A. Ärölä, K. V. V. Nurmela, P. Huhtanen, and J. M. Griinari. 2003. Effect of dietary fish oil on biohydrogenation of fatty acids and milk fatty acid content in cows. Anim. Sci. 77:165-179.
Shingfield, K. J., L. Bernard, C. Leroux, and Y. Chilliard. 2010. Role of trans fatty acids in the nutritional regulation of mammary lipogenesis in ruminants. Animal 4:1140-1166.

Shingfield, K. J., and J. M. Griinari. 2007. Role of biohydrogenation intermediates in milk fat depression. Eur. J. Lipid Sci. Technol. 109:799-816.

Shingfield, K. J., S. Jaakkola, and P. Huhtanen. 2001. Effects of level of nitrogen fertilizer application and various nitrogenous supplements on milk production and nitrogen utilization of dairy cows given grass silage-based diets. Anim. Sci. 73:541-554.

Shingfield, K. J., S. Jaakkola, and P. Huhtanen. 2002. Effect of forage conservation method, concentrate level and propylene glycol on diet digestibility, rumen fermentation, blood metabolite concentrations and nutrient utilisation of dairy cows. Anim. Feed Sci. Technol. 97:1-21.

Shingfield, K. J., C. K. Reynolds, G. Hervás, J. M. Griinari, A. S. Grandison, and D. E. Beever. 2006. Examination of the persistency of milk fatty acid composition responses to fish oil and sunflower oil in the diet of dairy cows. J. Dairy Sci. 89:714-732.

Tapio, I., D. Fischer, L. Blasco, M. Tapio, R. J. Wallace, A. R. Bayat, L. Ventto, M. Kahala, E. Negussie, K. J. Shingfield, and J. Vilkki. 2017. Taxon abundance, diversity, co-occurrence and network analysis of the ruminal microbiota in response to dietary changes in dairy cows. PLoS One 12:e0180260.

Urrutia, N. L., M. Toledo, M. Baldin, J. L. Ford, M. H. Green, and K. J. Harvatine. 2018. Kinetics of trans-10, cis-12 conjugated linoleic acid transfer to plasma and milk following an abomasal bolus in lactating dairy cows. Br. J. Nutr. 120:259-268.

Ventto, L., H. Leskinen, P. Kairenius, T. Stefański, A. R. Bayat, J. Vilkki, and K. J. Shingfield. 2017. Diet-induced milk fat depression is associated with alterations in ruminal biohydrogenation pathways and formation of novel fatty acid intermediates in lactating cows. Br. J. Nutr. 117:364-376.

Zened, A., F. Enjalbert, M. C. Nicot, and A. Troegeler-Meynadier. 2013. Starch plus sunflower oil addition to the diet of dry dairy cows results in a trans-11 to trans-10 shift of biohydrogenation. J. Dairy Sci. 96:451-459. 